Acta Universitatis Wratislaviensis No 3836

Anglica Wratislaviensia LVI, Wrocław 2018

DOI: $10.19195 / 0301-7966.56 .17$

Ewa Kucelman

ORCID: 0000-0003-1644-5787

Pedagogical University of Cracow

ewa.kucelman@up.krakow.pl

\title{
Cohesion - Between Instruction and Execution
}

\begin{abstract}
The paper seeks to present a practical use of reference chains analysis in the grading process of EFL university students' final practical English examination. The process of grading writing is always perceived as both tedious and subjective not only by the students but also by the examiners. The criteria listed by Cambridge English Language Assessment Department are very general, which makes examiners often adopt an impressionistic perspective while marking the content of the written assignment. At the same time, students often feel dissatisfied with the teacher's comments on their performance, they cannot clearly see the mistakes in the text structure they have made and often feel unfairly graded. Using reference chains and collocations as one of the steps in the process of written work evaluation makes it possible to put forward clear, straightforward criteria for text organization. It gives immediate insight into the text structure, paragraph organization, superstructure layout and the level of correspondence between the original task and the actual student's output. By being conducted as a series of precisely defined steps, according to a fixed checklist, it makes it possible for the examiner to draw objective criteria for grading writing. The empirical part of the paper focuses on the analysis of reference chains and collocations identified in the written examination of 15 first year students of English philology.
\end{abstract}

Keywords: discourse, text analysis, reference, reference chains, exam evaluation

\section{Introduction}

The study aimed at investigating the usefulness of reference chains and collocation (Halliday and Hasan 1976) in the process of evaluating writing tasks. Although as examples I use essays written by EFL students at my University, the techniques described are believed to be applicable at virtually all levels, provided the students are proficient enough to produce a structured, paragraphed text, for the grading of texts composed both by native and non-native speakers. 
Evaluating writing is often, albeit anecdotally, reported by examiners to be both a very tedious and complicated process. First of all, examiners are usually required to mark the papers with respect to a number of criteria. For example, Cambridge English Advanced. Handbook for teachers for exams from 2015 mentions four different assessment scales, ranging from 5 to 0 , for the writing tasks developed on the basis of the Common European Framework of Reference for Languages (CEFR):

- Content Scale - where the examiner evaluates the degree to which the examinee has fulfilled the task. This fulfillment is measured in terms of relevance and the examiner looks for potential irrelevancies or omissions which would adversely affect communication between the writer and the reader.

- Communicative Achievement Scale - where the knowledge (and a successful application) of "the conventions of the communicative task" is graded. What is more, the text is judged in terms of how successful the author is in "holding the target reader's attention" getting across "complex ideas".

- Organization Scale - where the coherence and logic of the text are graded. Additionally, the examiner evaluates the appropriateness of the use of different cohesive devices.

- Language Scale - which focuses on vocabulary and grammar in terms of their appropriateness and range.

Observing these criteria in practice is the source of many uncertainties among examiners, also because the guidelines as drawn by the Cambridge English Language Assessment are as imprecise as possible. Take, as an example, the Organization Scale. In order to get 5 points the examinee should produce a text which has the following features: "Text is a well-organised, coherent whole, using a variety of cohesive devices and organisational patterns with flexibility." 3 points are awarded to the author whose "text is well organised and coherent, using a variety of cohesive devices and organisational patterns to generally good effect." 1 point deserves a "text [which] is generally well organised and coherent, using a variety of linking words and cohesive devices." Obviously, such guidelines are of little objective help. Personally, I have no idea how to discriminate between "using a variety of devices with flexibility" and "using a variety of devices to generally good effect." Nor do other examiners. To make matters more complicated, there is the in-between case, namely 4 points, which are to be given to the author of the text whose organization level shares "features of Bands 3 and 5."

To deal with the above mentioned grading difficulties, some examiners develop their own marking criteria or otherwise they follow their intuition. In a very interesting study, albeit based on a slightly different scale, namely that drawn by IELTS for Academic Writing Task 2, Cotton and Wilson (2008) investigate how

${ }^{1}$ All quotes here are after Cambridge English Advanced. Handbook for teachers for exams from 2015: 36 . 
examiners approach the task of grading writing. Although their main interest is rating coherence and cohesion, their survey contains also a question where examiners are asked to rate all the four scales they use while grading writing, i.e. coherence and cohesion, grammatical range and accuracy, task response and lexical resource. The results show that the most examiners find coherence and cohesion the most difficult component to judge (66\%), while marking task response is the most difficult for $11 \%$ of the examiners, lexical range for $2 \%$, with not a single examiner finding grammatical range and accuracy the most difficult to grade (Cotton and Wilson 2008: 73). At the same time, however, the surveyed examiners do admit that there is a good deal of overlap between the four scales.

What is probably even more significant for the present study is the amount of attention devoted by Cotton and Wilson's subjects to evaluating coherence and cohesion respectively. The disproportion is astounding. Examiners were found to devote $72 \%$ of their assessment time to coherence with only $28 \%$ of their attention focused on explicit cohesive devices (Cotton and Wilson 2008:74). Even more surprisingly, some of the examiners could not give proper definitions for some cohesive devices, particularly reference and substitution, as illustrated by the quotes below (Cotton and Wilson 2008: 89):

“'Use of reference and substitution'. That doesn't mean very much to me. 'Can result in some repetition or error' Umm. No. that doesn't mean anything to me. (P)

Reference um, reference and substitution I'm inclined to put together in the sense of using pronouns to refer to something that's mentioned earlier. (L)"

Even though most examiners used most of their energy to evaluate coherence, the comments they made for the think-aloud protocols reveal that the criteria they use to mark coherence are extremely vague and subjective. Cotton and Wilson (2008: 80) quote the following comments:

It's just a bit incoherent.

There's coherence there.

Not sure that makes sense.

There is a good level of clarity and fluency in this piece of writing on the whole though.

It's not fluent. There lacks fluency.

Well the sentences sort of flow on nicely.

But the fluency and logic flow is not clear.

So it's quite easy to go through and follow what the person is saying.

It's pretty good, it flows quite well.

With such vague and subjective criteria, one would assume that different examiners would mark the same piece of writing differently. Surprisingly, Cotton and Wilson (2008: 106) report no significant differences in exam marking among examiners with different "marking experience, higher qualifications, training in linguistics, and either the level of most teaching experience or for the number of years of teaching experience." These findings go against my personal, although unfortunately undocumented, experience as a member of workshops for examiners 
grading the Polish Matura 2000 English writing tasks, where the same piece could score 5 (the highest possible grade at the time) or 3 (the lowest passing grade at the time), with examiners reluctant both to justify explicitly and amend their judgments.

So far I have focused on a rather narrow field of examiners' correction of examination papers, completely neglecting the second party involved, namely the examinees. For my students, the exam itself is only the crowning of a yearlong (or even longer) process of preparation, during which the students are given detailed instructions on how particular types of writing assignments should be dealt with and, hopefully, are expected to submit a number of writing tasks to be evaluated. This brings us to the last key issue, that is feedback. When the students have their writing graded, they expect, quite rightly, to get detailed and informative feedback. While teachers / examiners usually find it quite easy to account for grammatical or lexical shortcomings of the evaluated text, what students often get while asking about the grades for the organization component closely resembles the comments quoted above. In personal communication, students have frequently remarked to me that they do not find such explanations helpful, and especially during exams, they find them unconvincing, feeling that they have been unfairly treated.

To round off this rather long introductory section, I do not dare to claim that reference chains are the cure for all diseases, but I do believe that they provide at least partial evidence for what an experienced examiner will probably see intuitively. As will be shown below, although reference is one of the features of cohesion, its usefulness in the process of grading writing is not limited to the organization component. By pointing to specific overt elements, grading appears to be more objective than when referring to subjective intuitive general impressions. The method I present here is just a rough idea to be discussed, refined and elaborated on.

\section{Cohesion and coherence - a review}

\subsection{Cohesion}

The concept of cohesion was first introduced by Halliday and Hasan (1976: 4) to refer to different meaning relations which go beyond the structure of a sentence and which make a collection of sentences a text. Two aspects or types of cohesion are usually distinguished, grammatical and lexical cohesion. Grammatical cohesion is based on the use of grammatical devices among which one finds reference, ellipsis, substitution and conjunction. Lexical cohesion, on the other hand, relies on reiteration and collocation.

Reference refers to the relationship between one discourse element in the text and another one which either precedes or follows it. This kind of relationship can be achieved in a number of ways, ranging from repetition (1a), through partial 
repetition (1b), lexical replacement (1c) pronominalization (1d) to pro-form substitution (1e) and ellipsis (1f), as illustrated below (Halliday and Hasan 1976: 143):

1. a. The Prime Minister recorded her thanks to the Foreign Secretary. The Prime Minister was most eloquent.

b. Dr E. C. R. Reeve chaired the meeting. Dr Reeve invited Mr Phillips to report on the state of the gardens.

c. Ro's daughter is ill again. The child is hardly ever well.

d. Ro said she would have to take Sophie to the doctor.

e. Jules has a birthday next month. Elspeth has one too.

f. Jules has a birthday next month. Elspeth has [...] too.

As can be seen, reference, as understood by Halliday and Hasan, overlaps with other cohesive devices. And so, the use of a synonymous noun 'child' to refer to 'daughter' in (1c) is both grammatical and lexical. Pronominalization and proform substitution are related through the application of a form whose interpretation entirely depends on the element it refers to or substitutes. In (1d) 'she' can denote any female (human) being. What it does refer to is only disambiguated by making a reference link between 'she' and 'Ro'. Similarly, in (1e) 'one' may refer to any countable noun, here we need to link it referentially with 'birthday'. In contrast, one would normally assume that 'the Prime Minister' (1a) or 'Dr Reeve' (1b) will refer to the same individual whenever they appear in the text. Therefore, from the point of view of text interpretation, repetition and partial repetition are the easiest to interpret, while the careless or indeed incorrect application of pronominalization or substitution may lead to ambiguity or misunderstanding.

Ellipsis is usually defined as grammatical omission conditioned by recoverability. Referentially conditioned ellipsis, as in (1f) should be distinguished from purely grammatically triggered one. Grammatically conditioned ellipsis, such as the omission of 'that' in the sentence I think (that) this project is worth considering, does not represent cohesion.

The last type of grammatical devices, namely conjunction is probably also the one most frequently mentioned with reference to cohesion. It is a relationship which indicates how the subsequent clause or sentence is linked to the preceding one. The most frequent relationships are those of addition, temporality, causality. Conjunction may take two forms known as hypotactic relationships, where the main clause is linked with a subordinate clause (examples a below) and paratactic relationships, in which we deal with two main clauses (examples b).

\section{Addition}

a. Besides being mean, he is also hateful.

b. He no longer goes to school and is planning to look for a job. 
3. Temporality

a. After the car had been repaired, we were able to continue our journey.

b. The car war repaired. Afterwards, we were able to continue our journey.

4. Causality

a. He is not going to school today because he is sick.

Ann got a beautiful job last year and now she is rich.

(Renkema 2004: 104)

Lexical cohesion, as mentioned above, is achieved either through reiteration or collocation. Reiteration may include verbatim repetition and the use of other semantic relations such as synonymy, hyponymy, meronymy and antonymy, as illustrated below:

5. Repetition (involves reference)

A conference will be held on national environmental policy. At this conference the issue of salination will play an important role.

6. Synonymy (involves reference)

A conference will be held on national environmental policy. This environmental symposium will be primarily a conference dealing with water.

7. Hyponymy

We were in town today shopping for furniture. We saw a lovely table.

8. Meronymy

At its six-month checkup, the brakes had to be repaired. In general, however, the car was in good condition.

9. Antonymy

The old movies just don't do it any more. The new ones are more appealing. (Renkema 2004: 105)

While reiteration is rather unproblematic, collocation has raised a number of controversies. Even the term itself is controversial, as it brings to mind a notion used in lexicography in a completely different sense. Halliday and Hasan (1976: 284) understand collocation as "cohesion that is achieved through the association of lexical items that regularly co-occur." For example, the use of the word 'government' is collocated with 'politicians', 'ministers', 'bill' etc. In fact, there have appeared a few alternatives to "collocation". Even Hasan herself (Hasan 1984), sees the imprecision of the originally used term "collocation" and tries to refine it by dividing it into "general collocations", by which she means semantic relations of synonymy, antonymy, hyponymy, etc. and "instantial collocations" created by text relations of equivalence, naming, semblance. Enkvist (1975) replaces "collocation" with "implication", while Källgren (1979) uses the term "inference". Terminology may differ, but what remains a fact, however, is that unlike lexical relations, which 
are usually strengthened by reference, collocation remains subjective, therefore difficult to evaluate according to a set of fixed criteria.

\subsection{Cohesive harmony}

Cohesive harmony was developed by Hasan $(1984,1985)$ as a method of evaluating text coherence. What makes text coherent are the lexical and grammatical patterns called cohesive ties, which are present in the text. Whenever there exists a semantic connection between words in a text, these words form a cohesive chain. There are two main types of cohesive chains, namely identity chains and similarity chains. Identity chains, as the name suggests point to the identity of entities, usually people or things. They involve the presence of grammatical cohesive devices such as pronouns or demonstratives and are based on co-reference. Similarity chains are formed by open class items, such as nouns, verbs or adjectives and based upon lexical cohesive devices. There exists one more type of cohesive chains, i.e. equivalent chains, which differ from the previously mentioned ones in that the chains which are formed are 'instantial'. They exist only in a given text and the co-occurrence of the same lexical items outside the text will be interpreted as accidental. Equivalent chains are based on comparison and they often involve metaphoric relations. An element in a text which is part of a chain is called a 'central' token, while an element which is not part of a chain is referred to as a 'peripheral' taken. Cohesive chains contribute to the cohesive harmony only when they are connected or they interact, that is when tokens in two different chains serve the same grammatical roles at least twice.

Chains are source of valuable quantitative information. They point to the density of cohesive devices in the text, which in turn may be used to evaluate coherence. Hasan (1985) makes the following assumptions:

- the lower the number of peripheral tokens, the greater the coherence

- the higher the proportion of central to non-central tokens, the greater the coherence

- the fewer breaks in interaction chains, the greater the coherence.

On the other hand, as Hasan (1985:94) states: "cohesion is the foundation on which the edifice of coherence is built. Like all foundations, it is necessary but not sufficient by itself." Therefore even a high density of cohesive devices does not automatically make the text coherent.

This means that cohesive harmony itself is an insufficient means for the measurement of coherence. But even if limited to the analysis of cohesion, it seems to be an incomplete tool. What it does not take into consideration is conjunction analysis. This means that often we know who or what but we do not know when and why. In other words, the temporal and causal organization of the text remains unaccounted for. 


\subsection{Coherence}

The term coherence has already appeared a number of times in the previous sections as coherence and cohesion are so closely related that it seems impossible to discuss one without making reference to the other. While cohesion is basically limited to the text itself, coherence takes into account the context. In other words, cohesion is the property of text, but coherence belongs to the interpretative system of the recipient of the text. It involves the connections that the recipient makes between sentences on the base of their knowledge and previous experience. In this way, the recipient makes links between utterances which seem completely unrelated as in the famous Widdowson's (1978: 29) example:

10. A: That's the telephone.

B: I'm in the bath.

A: Ok.

The relationship between coherence and cohesion has been widely discussed in literature, with researches presenting very different, even extreme points of view. For Halliday and Hasan (1976), coherence and cohesion are completely separate issues, where cohesion simply means text coherence and coherence takes into account the situation. A similar opinion is expressed by de Beaugrande (1980), for whom coherence and cohesion are not only separate but also unrelated. On the other end of the spectrum we have Enkvist (1990), who claims that the difference between coherence and cohesion has been artificially made by linguists and it is not grounded in language as such or Carrell (1982), who calls cohesion an illusion.

The main problem for those researches who see the two notions as related is the precise nature of their relationship. It has been demonstrated above in example (10) that a text lacking cohesive devices may be perfectly coherent. Enkvist (1978) provides an example of a cohesive text which makes no sense:

11. The discussions ended last week. A week has seven days. Every day I feed my cat. Cats have four legs. The cat is on the mat. Mat has three letters.

On the basis of examples similar to those quoted in (10) and (11), some linguists, for example Morgan and Sellner (1980), come to the conclusion that cohesion does not play any significant role in text analysis. On the other hand, experiments carried out by van Peer (1989) proved that the audience do not find manipulated texts, such as (12):

12. Mick Jagger recently preferred to skip his birthday celebration. "He is shocked he is already forty", she said. His mother revealed why:

"as coherent as the original ones". 
This means that although cohesion itself is not enough, it facilitates the process of text interpretation. Brown and Yule (1983: 198) note that speakers consciously choose which cohesive devices to use to make themselves better understood.

The study by Cotton and Wilson (2008), mentioned in the introductory section, revealed that examiners themselves pay more attention to coherence than to cohesion when marking writing. However, as Tanskanen (2006: 21) remarks, cohesion is more objective than coherence, for it depends on explicit devices, which can be measured, evaluated and counted, while coherence will vary from speaker to speaker. In the following sections the theory described so far will be utilized to draw up an objective tool to evaluate writing.

\section{Aims, objectives and methodology}

The aim of my research was quite simple, as I attempted to check to what extent Hasan's reference chains may prove useful in the process of marking writing. The immediate trigger were numerous informal talks with my students, who constantly complain about the fact that while they can easily see their teachers' points concerning grammatical correctness and the use of vocabulary, they often feel dissatisfied with or unconvinced by the teacher's comments on the technical side of their writing, i.e. the structure of their compositions and their way of dealing with the exam question. Additionally I looked at collocation as defined by Halliday and Hasan (1976). The analysis of reference chains and collocation made it possible to make certain observations concerning:

- text organisation,

- paragraphing,

- content relevance,

— vocabulary range (to some extent).

\subsection{The procedure}

15 essays written as one of the components of the final practical English examination taken by first year students of English philology of Pedagogical University of Cracow constituted the material for the analysis. The students represented B2 level and had been given a yearly intensive course at the advanced level, including 30 hours of writing. The students practiced writing forms which are required at the CAE examination. The final examination was intended to be an achievement rather than a proficiency test. This meant that the exam tasks were supposed to reflect the content of the course, both as far as language is concerned and in terms of the task types. At the exam, the students were given a choice of three tasks: a letter of complaint, a review and a proposal. The task was to be written in approximately 250 words. For my analysis I chose those papers which concerned the second task, 
i.e. the reviews. The reviews were chosen by 14 female students and one male student. The task was worded as follows:

An International magazine has asked its readers to send in a review of two different English-language websites they would recommend, commenting on:

- ease of navigation

— range of information/products available

— any special features.

Since the review concerns two websites, the first step was to identify in each composition two reference chains, each for one website. The analysis of these chains proved helpful in answering the following questions:

- Are both chains equally long?

The assumption: If the author devotes the same amount of attention to each website, the chains should be of approximate length.

- What elements make up the chains?

The assumption: The easiest option is to use pronouns, so higher-performing students will use lexical cohesive devices, for example synonyms, meronyms etc.

- How are the chains distributed throughout the paragraphs?

The assumption: The distribution of the chains will reveal and reflect the organization of the composition. It will also reveal a lack of harmony in paragraphing.

The second procedure, that is collocation identification, was applied to evaluate the execution of the more specific sub-tasks, i.e. what and how the student writes about the navigation and products / information available. The collected collocations can be utilized to the following purposes:

- to check whether the student does write about both

- to gather information about what exactly is it that the student mentions while dealing with these two issues. For example, in answer to the question about navigation, does the student go beyond simply stating that the navigation is easy or difficult, i.e. are there any elaborations, justifications, etc. used to make the claim clearer and stronger.

- quantitatively, how much attention is devoted to each of the two points. Is it distributed equally or are there any discrepancies?

- finally, since the exam is supposed to be an achievement test, the examination of collocation will make it possible to evaluate the range of key vocabulary.

\subsection{The limitations of the procedure}

The procedure described above is not meant to replace the standard writing grading procedures. Nor does it aspire to highlight all aspects of the written tasks which are typically evaluated. First of all, it does not deal with the language component. The use of grammatical structures lies completely outside the scope of the procedure. Nor does the procedure make it possible to make a precise judgment of the range 
of vocabulary used. Although the examination of collocation does provide us with some information concerning the command of the so-called 'key vocabulary', that is vocabulary which is closely tied with the topic of the examination task. Similarly, by examining the links that form the reference chains, we obtain information about the flexibility of the author with synonyms, antonyms and other lexical relations within the very limited sphere of task related vocabulary. In other words, the procedure gives some insight into the degree to which the student has mastered the vocabulary, i.e. lexical achievement level, but it does not provide any kind of assistance when it comes to the general range of vocabulary used in the composition.

This is not necessarily a major drawback, for marking the language component is reported by the examiners to be fairly straightforward and objective, at least as Cotton and Wilson's (2008) data show. My personal experience and private conversations with students reveal that students usually accept teachers' or examiners' judgments of their command of language. Grammatical mistakes can be easily pointed to, counted or even divided into more or less 'cardinal'.

The other very important aspect that is completely neglected by the procedure is coherence. This does seem to be a drawback. First of all, the organization component of the grading scale includes both coherence and cohesion. However, as already noted, if coherence is defined as the connections made by the recipient then it is by nature subjective. What is more, if coherence is based on an individual's personal experience and knowledge, it is not a simple task to define what makes the text coherent. On the other hand, if one makes an assumption that at least in an examination format, the student consciously decides to utilize certain cohesive devices to facilitate comprehension, then cohesion chains may be treated as the indication of coherence.

The most significant omission, however, is the absence of the analysis of conjunction, which is an essential component of cohesion. And once again, conjunction by being overtly marked is countable, measurable and easily detectable. Consequently, no special procedure is necessary.

\subsection{The application of the procedure}

As mentioned above, the procedure is not meant as a replacement of the standard form of exam marking but as its supplementation and extension aimed at extracting more objective data which would support the examiner's intuitions. Therefore the suggested procedure would be to start with regular marking and when this is completed to carry out the reference chain and collocation analysis. 


\section{Data analysis and discussion}

\subsection{Reference chains}

As described above for the fifteen analysed reviews, two reference chains have been identified, one for each website. The chains obviously cut across paragraphs, but for the sake of the analysis, the chains have been divided by means of double slanting lines into paragraphs. Whenever there is no link present in a given paragraph, this fact is signaled through a dash. The $\varnothing$ symbol represents ellipsis as a link in the chain. The chains are presented in Table 1:

Table 1: Reference chains in the examined sample

\begin{tabular}{|c|c|c|c|c|}
\hline $\begin{array}{l}\text { Student } \\
\text { Initials }\end{array}$ & Site 1 & $\begin{array}{l}\text { Number } \\
\text { of links }\end{array}$ & Site 2 & $\begin{array}{c}\text { Number } \\
\text { of links }\end{array}$ \\
\hline $\mathrm{BD}$ & $\begin{array}{l}\text { everydayEnglish.com-they } \\
\text { both-everydayEnglish. } \\
\text { com- the first website-both } \\
\text { websites -they // this sites- } \\
\text { both } \varnothing \text {-they -their-them- } \\
\text { everydayEnglish.com }\end{array}$ & 12 & $\begin{array}{l}\text { englishtexts.com -they } \\
\text { both -the second one- a } \\
\text { site-both websites-they } \\
\text {-englishtexts.com // sites- } \\
\text { both Ø -they -their -them } \\
\text {-englishtext.com }\end{array}$ & 13 \\
\hline $\mathrm{AF}$ & $\begin{array}{l}\mathrm{BBC} / / \text { the BBC website- } \\
\text { it-it-this website-it // the } \\
\mathrm{BBC} \text { website-the first } \\
\text { website //the BBC and } \\
\text { Ebay websites-the BBC }\end{array}$ & 10 & $\begin{array}{l}\text { Ebay //-// Ebay- this } \\
\text { website // the BBC and } \\
\text { Ebay websites }\end{array}$ & 4 \\
\hline $\mathrm{KD}$ & $\begin{array}{l}\text { www.gumtree.com // } \\
\text { gumtree -a website -this } \\
\text { website // Gumtree // - // } \\
-/ / / / /-\end{array}$ & 4 & $\begin{array}{l}\text { WWW.vissavi.com // - //-// } \\
\text { vissavi.com -a website // } \\
\text { the main page //vissavi // } \\
\text { this website }\end{array}$ & 6 \\
\hline NF & $\begin{array}{l}\text { E-bay -this website -E-bay- } \\
\text { it -E-bay's //- // both of the } \\
\text { websites -which one }\end{array}$ & 7 & $\begin{array}{l}\text {-// the second most suitable } \\
\text { website -Forever 21-this } \\
\text { website -its (name)- the } \\
\text { website -this online shop } \\
\text { // both of the websites } \\
\text {-which one }\end{array}$ & 8 \\
\hline $\mathrm{AD}$ & $\begin{array}{l}\text { Xojane.com // this site- } \\
\text { this-it-Xojane.com - this } \\
\text { site -its //- // these two } \\
\text { websites }\end{array}$ & 8 & $\begin{array}{l}\text {-//-//- other page -its- } \\
\text { Goodreads.com-there } \\
\text {-Goodreads-a forum -its // } \\
\text { these two websites }\end{array}$ & 8 \\
\hline MF & $\begin{array}{l}\text {-//Rookie.com-a magazine } \\
\text {-it -Rookie -this site- } \\
\text { Rookie -it //- // which page } \\
\text {-both of them }\end{array}$ & 9 & $\begin{array}{l}\text {-//- // another website } \\
\text {-TED -it -a page -there // } \\
\text { which page-TED -both of } \\
\text { them }\end{array}$ & 8 \\
\hline
\end{tabular}




\begin{tabular}{|c|c|c|c|c|}
\hline $\mathrm{MG}$ & $\begin{array}{l}\text { 9GAG // - // 9GAG -a } \\
\text { website -there -there -this } \\
\text { website -9GAG.com // } \\
\text { 9GAG }\end{array}$ & 8 & $\begin{array}{l}\text { ebay // Ebay -an } \\
\text { internation auction service } \\
\text {-it -this-a website- it } \\
\text { //- // ebay- a website -it's } \\
\text { (meaning its) }\end{array}$ & 10 \\
\hline PD & $\begin{array}{l}\text {-// the first site- } \\
\text { DeviantART.com- it-a } \\
\text { page-its -it // Deviant.ART } \\
\text { // DeviantART -it -a great } \\
\text { place }\end{array}$ & 10 & $\begin{array}{l}\text {-// - // the other place } \\
\text {-danborn.com -it -a site-it } \\
\text {-its // - }\end{array}$ & 6 \\
\hline $\mathrm{KS}$ & $\begin{array}{l}\text {-//two different websites- } \\
\text { the first one -easyenglish } \\
\text {-a website -it -the website } \\
\text {-the website // the previous } \\
\text { one // both websites -the } \\
\text { first one }\end{array}$ & 10 & $\begin{array}{l}\text {-// two different websites } \\
/ / \text { the second website } \\
\text {-languagesforall -the } \\
\text { websites (the intended } \\
\text { reference is singular) -this } \\
\text { website // both websites- } \\
\text { the second one }\end{array}$ & 7 \\
\hline MS & $\begin{array}{l}\text {-// BBC Learning English } \\
\text {-this website -the website } \\
\text {-the website -BBC } \\
\text { Learning English -it -it // } \\
\text { both pages-they -the first } \\
\text { one }\end{array}$ & 10 & $\begin{array}{l}-/ / \text { - // second page -Daily } \\
\text { News -It-This website } \\
\text { // both pages -they -the } \\
\text { second }\end{array}$ & 7 \\
\hline AT & $\begin{array}{l}\text { Coffetivity-the websites- } \\
\text { they -they //Coffetivity -the } \\
\text { website // the Coffetivity - } \\
\text { // Coffetivity-they-them }\end{array}$ & 10 & $\begin{array}{l}\text { English Matters!-the } \\
\text { websites -they-they //- // } \\
\text { English Matters -it // - // } \\
\text { English Matters! -the } \\
\text { English Matters!-they } \\
\text {-them }\end{array}$ & 10 \\
\hline EB & $\begin{array}{l}\text {-// The first one -a very } \\
\text { famous website -'your } \\
\text { music taste'- this site -here } \\
/ / \text { - // both websites - the } \\
\text { first one }\end{array}$ & 7 & $\begin{array}{l}\text {-// - // My second choice- } \\
\text { www.useless_knowledge. } \\
\text { com -this website-it-it-it-it } \\
\text { // both websites-the second } \\
\text { one-its }\end{array}$ & 10 \\
\hline $\mathrm{AB}$ & $\begin{array}{l}\text { A SkyDance shop // } \\
\text { SkyDance -a web shop- } \\
\text { the shop's // - // these two } \\
\text { websites }\end{array}$ & 5 & $\begin{array}{l}\text { an English Wikipedia } \\
\text { //- // another webpage } \\
\text {-Wikipedia -the biggest } \\
\text { encyclopedia -it // these } \\
\text { two websites }\end{array}$ & 7 \\
\hline
\end{tabular}




\begin{tabular}{|l|l|c|l|c|}
\hline AA & $\begin{array}{l}\text { two of them -The first // } \\
\text { the website -there -it -the } \\
\text { website // - // these two } \\
\text { English language websites } \\
\text {-them -both }\end{array}$ & 9 & $\begin{array}{l}\text { two of them-the second } \\
\text {-BBC website // - // } \\
\text { Another website -BBC } \\
\text { website -there -it -it // } \\
\text { these two English language } \\
\text { websites -them-both-BBC } \\
\text { website }\end{array}$ & 11 \\
\hline RB & $\begin{array}{l}\text { ebay.com - the former- a } \\
\text { vitual marketplace // ebay. } \\
\text { com -it -it- it -ebay // - // } \\
\text { the two aforementioned } \\
\text { websites-their }\end{array}$ & 10 & $\begin{array}{l}\text { armmorgames.com -the } \\
\text { latter // - // armogames.com } \\
\text { //the two aforementioned } \\
\text { websites -their }\end{array}$ & 5 \\
\hline
\end{tabular}

As the above table shows, in the majority of the cases the two reference chains are of equal length, which suggests that the authors devoted an approximately equal amount of attention to both sites. The exceptions are three students: AF (the first chain 10 links and the second only 4), PD (10 links vs 6 links) and RB (10 links vs 5 links). Such disproportions may, but they do not have to indicate that there is some disproportion in the treatment of the two sites. For AF this seems to be the case. While she devotes a lot of attention to the first site as such, in her description of the second site, she is almost entirely interested in the presentation of the products available, leaving out the layout and the technicalities. Although AF tries to make reference to the navigation of the second site, she makes a grammatical mistake, which results in the lack of a link. A similar problem appears in RB's essay. PD makes a different mistake. In the main body of her compostion, she devotes equal attention to both sites and the number of links for both sites is similar in the main body of the composition. The disproportion is due to the fact that in the concluding paragraph, PD makes reference only to the first site.

Another useful piece of information that is provided by reference chains concerns the layout of the composition. For a task such as the one analysed, the expected layout would be four paragraphs, where the first paragraph would serve as the introduction, the second would present the first website, the third would be devoted to the second website and the last one would serve as the conclusion. Consequently, we would assume that both chains will be traced in the first paragraph. The second and the third paragraph will be devoted to site one and site two respectively with an occasional link of the other chain if comparison between the sites is made. In the concluding paragraph again both chains are to be found. What was actually encountered in the students' essays is presented in Table 2: 
Table 2: The distribution of cohesive chains across paragraphs

\begin{tabular}{|c|c|c|c|c|}
\hline Student & $1^{\text {st }}$ paragraph & $2^{\text {nd }}$ paragraph & $3^{\text {rd }}$ paragraph & $4^{\text {th }}$ paragraph \\
\hline $\mathrm{BD}$ & no & both chains & both chains & no \\
\hline $\mathrm{AF}$ & both & Chain 1 & both chains & both chains \\
\hline $\mathrm{KD}$ & both & $\begin{array}{l}\text { Chain } 1 \text { (two } \\
\text { paragraphs) }\end{array}$ & $\begin{array}{l}\text { Chain } 2 \text { (four } \\
\text { paragraphs) }\end{array}$ & no \\
\hline NF & no & Chain 1 & Chain 2 & both chains \\
\hline $\mathrm{AD}$ & Chain 1 & Chain 1 & Chain 2 & both chains \\
\hline MF & both chains & Chain 1 & Chain 2 & both chains \\
\hline MG & both chains & Chain 2 & Chain 1 & both chains \\
\hline PD & - & Chain 1 & both chains & Chain 1 \\
\hline $\mathrm{KS}$ & - & both chains & both chains & both chains \\
\hline MS & - & Chain 1 & Chain 2 & both chains \\
\hline AT & both chains & Chain 1 & both chains & both chains \\
\hline EB & - & Chain 1 & Chain 2 & both chains \\
\hline $\mathrm{AB}$ & both chains & Chain 1 & Chain 2 & both chains \\
\hline AA & both chains & Chain 1 & Chain 2 & both chains \\
\hline $\mathrm{RB}$ & both chains & Chain 1 & Chain 2 & both chains \\
\hline
\end{tabular}

The majority of essays conform to the predicted layout, with some visible tendencies concerning the introduction. One of these tendencies is to mention both sites in the introduction, the other to make the introduction more general with the names of the sites first appearing in the main body of the composition. The chains also illustrate two strategies that the students apply while describing the sites. The first strategy applied is to discuss the sites separately (those are marked in Table 2 as Chain 1 in the $2^{\text {nd }}$ paragraph and Chain 2 in the $3^{\text {rd }}$ one), the second one is to devote a paragraph to each site, while making comparisons of the sites in one or both paragraphs (those are marked in Table 2 as both chains in the $2^{\text {nd }}$ or / and the $3^{\text {rd }}$ paragraph). "Deviant" layouts can be observed for the students coded as $\mathrm{BD}, \mathrm{KD}, \mathrm{NF}, \mathrm{AD}, \mathrm{MG}, \mathrm{PD}$, each representing a different shortcoming. In BD's composition there is no introduction and no conclusion, in KD's essay the text is chopped into a sequence of many extremely short paragraphs, none of which could be clearly labelled as the concluding one, NF did not introduce the topic properly, 
$\mathrm{AD}$ does include the introductory paragraph, but devotes it only to the first site, PD's composition has a similar flaw but in the concluding paragraph, while MG's mistake in the layout is a minor one, with site 2 discussed before site 1 .

Another application of reference chains is to evaluate the students' flexibility at using different types of cohesive devices. Here I have made quantitative analysis, adding up all tokens that represent the same type for each student. The results are presented in Table 3:

Table 3: The quantitative analysis of the students' use of cohesive devices

\begin{tabular}{|l|c|c|c|c|c|c|c|c|}
\hline & $\begin{array}{l}\text { Repeti- } \\
\text { tion }\end{array}$ & $\begin{array}{l}\text { Partial } \\
\text { Repeti- } \\
\text { tion }\end{array}$ & $\begin{array}{l}\text { Lexical } \\
\text { Replace- } \\
\text { ment }\end{array}$ & $\begin{array}{l}\text { Pronomi- } \\
\text { nalization }\end{array}$ & $\begin{array}{l}\text { Pro-form } \\
\text { Substi- } \\
\text { tution }\end{array}$ & Ellipsis & Meronymy & Total \\
\hline BD & 4 & - & 7 & 12 & - & - & - & 23 \\
\hline AF & 2 & 4 & 3 & 3 & - & - & 1 & 13 \\
\hline KD & - & 4 & 4 & - & - & - & - & 8 \\
\hline NF & 2 & 3 & 4 & 2 & 2 & - & - & 13 \\
\hline AD & 1 & - & 5 & 5 & 1 & - & 2 & 14 \\
\hline MF & 1 & 2 & 3 & 4 & 2 & - & 3 & 15 \\
\hline MG & 4 & 1 & 5 & 4 & 2 & - & - & 16 \\
\hline PD & - & 3 & 3 & 7 & - & - & - & 13 \\
\hline KS & - & - & 8 & 3 & 3 & 1 & - & 15 \\
\hline MS & 1 & - & 7 & 5 & 1 & 1 & - & 15 \\
\hline AT & 6 & - & 3 & 9 & - & 1 & - & 19 \\
\hline EB & - & - & 6 & 4 & 5 & - & - & 15 \\
\hline AB & - & 2 & 7 & 1 & - & - & - & 10 \\
\hline AA & 2 & - & 4 & 8 & 2 & 2 & - & 18 \\
\hline RB & 2 & 1 & 3 & 5 & 2 & - & - & 13 \\
\hline
\end{tabular}

The data presented above clearly show that the students generally use a variety of cohesive devices. As predicted by Cotton and Wilson (2008), the most frequently used devices include pronominalization and lexical replacement (chiefly synonymy), followed by replacement or partial replacement but contrary to their predictions, pro-form substitution is quite frequently applied. The rarest grammatical cohesive device in the analysed sample seems to be ellipsis, again as Cotton and Wilson predict. When it comes to lexical cohesion, apart from the very popular synonymy, 4 students reached for meronymy. Here, however, the interpretation of 
the links was a bit difficult, as Polish students tend to confuse the terms site and page. Consequently, each use of this word had to be considered individually. Other lexical relations were not detected. Of course this kind of information is useful during the semester, rather than at the examination time, so that if certain devices are underused, the teacher still has time to practice them in class.

\subsection{Collocation}

The second part of the procedure applied consisted in noting down collocations for the two features of the websites the students were to describe, namely ease of navigation and range of information/products available. The collocations, each constituting one token, the students used in their writing are presented in Table 4 and Table 5:

Table 4: The students' collocations for the "ease of navigation"

\begin{tabular}{|c|c|c|c|c|}
\hline & Site 1 & tokens & Site 2 & tokens \\
\hline $\mathrm{BD}$ & $\begin{array}{l}\text { simply-designed menu // } \\
\text { open a site // you can choose } \\
\text { things to learn //appropriate } \\
\text { lesson opens // may get lost } \\
\text { in a huge number of choices } \\
\text { on the first website }\end{array}$ & 5 & $\begin{array}{l}\text { simply-designed menu // } \\
\text { everything on one page }\end{array}$ & 2 \\
\hline $\mathrm{AF}$ & $\begin{array}{l}\text { easy to navigate // everything } \\
\text { is clear // you don't get stuck }\end{array}$ & 3 & $\begin{array}{l}\text { as easy to navigate as the first } \\
\text { website // you will not get } \\
\text { lost or confused }\end{array}$ & 2 \\
\hline $\mathrm{KD}$ & $\begin{array}{l}\text { easy to navigate //just one } \\
\text { simple click of the mouse } \\
\text { // typing a key word in the } \\
\text { search box }\end{array}$ & 3 & $\begin{array}{l}\text { all sort of information pops } \\
\text { up // we click on a piece of } \\
\text { clothing }\end{array}$ & 2 \\
\hline NF & - & 0 & $\begin{array}{l}\text { easily navigated by typing its } \\
\text { name on Google }\end{array}$ & 1 \\
\hline $\mathrm{AD}$ & $\begin{array}{l}\text { simple division to categories } \\
\text { // navigation of Xojane.com } \\
\text { is pretty easy }\end{array}$ & 2 & $\begin{array}{l}\text { graphic design is messy, what } \\
\text { makes finding information } \\
\text { harder }\end{array}$ & 1 \\
\hline MF & $\begin{array}{l}\text { incredibly easy to navigate // } \\
\text { everything on your right side } \\
\text { // a dropdown menu }\end{array}$ & 3 & easy to navigate // search bar & 2 \\
\hline MG & fairly easy to navigate & 1 & $\begin{array}{l}\text { content divided to many } \\
\text { categories // pleasant to } \\
\text { navigate }\end{array}$ & 2 \\
\hline
\end{tabular}




\begin{tabular}{|c|c|c|c|c|}
\hline PD & $\begin{array}{l}\text { the navigation is easy and } \\
\text { user friendly }\end{array}$ & 1 & hard to navigate & 1 \\
\hline KS & easy to navigate & 1 & $\begin{array}{l}\text { the navigation may prove to } \\
\text { be tricky }\end{array}$ & 1 \\
\hline MS & $\begin{array}{l}\text { navigation of the website } \\
\text { is easy // the icons are big } \\
\text { enough }\end{array}$ & 2 & $\begin{array}{l}\text { nicely and clearly organized } \\
/ / \text { sometimes letters are too } \\
\text { small to be read }\end{array}$ & 2 \\
\hline AT & $\begin{array}{l}\text { navigation is so easy // } \\
\text { products are listed on the } \\
\text { right side// you can choose }\end{array}$ & 3 & $\begin{array}{l}\text { the navigation may seem not } \\
\text { as clear as on loffetivity // the } \\
\text { sections appear // click at a } \\
\text { big blue flower }\end{array}$ & \\
\hline EB & - & 0 & - & 0 \\
\hline $\mathrm{AB}$ & $\begin{array}{l}\text { everything is on the main } \\
\text { page// won't be lost in the } \\
\text { categories }\end{array}$ & 2 & $\begin{array}{l}\text { categories are clearly } \\
\text { arranged // 'search' is visible } \\
\text { on the top }\end{array}$ & 2 \\
\hline AA & $\begin{array}{l}\text { there aren't any problems } \\
\text { with navigation on the } \\
\text { website // the list of topics } \\
\text { is written clearly // big } \\
\text { headlines }\end{array}$ & 3 & $\begin{array}{l}\text { of links and headlines written } \\
\text { in capital letters // navigation } \\
\text { is not problematic }\end{array}$ & 2 \\
\hline $\mathrm{RB}$ & $\begin{array}{l}\text { ease of navigation // a built-in } \\
\text { search engine// allowing for } \\
\text { complex search // with many } \\
\text { variables// choice of category, } \\
\text { price, range, user score and } \\
\text { tags }\end{array}$ & 5 & $\begin{array}{l}\text { easly browse } / / \text { in terms of } \\
\text { genre and user score }\end{array}$ & 2 \\
\hline
\end{tabular}

Table 5: The students' collocations for the range of information/products available

\begin{tabular}{|l|l|c|l|c|}
\hline & \multicolumn{1}{|c|}{ Site 1 } & tokens & \multicolumn{1}{|c|}{ Site 2 } & tokens \\
\hline BD & $\begin{array}{l}\text { appropriate lesson // well- } \\
\text { written lesson //diversity of } \\
\text { different levels //for all ages } \\
/ / \text { lots of exercises // well- } \\
\text { written exercises }\end{array}$ & 6 & $\begin{array}{l}\text { well written lesson // } \\
\text { diversity of different levels // } \\
\text { for all ages //lots of exercises } \\
/ / \text { sell books and workbooks } \\
\text { // exercises are demanding // } \\
\text { well-written exercises }\end{array}$ & 7 \\
\hline AF & $\begin{array}{l}\text { news from the whole world // } \\
\text { the comedy // science // many } \\
\text { other programs }\end{array}$ & 4 & $\begin{array}{l}\text { buy something // a piece of } \\
\text { furniture // the variety of } \\
\text { products sold there is wide }\end{array}$ & 3 \\
\hline
\end{tabular}




\begin{tabular}{|c|c|c|c|c|}
\hline $\mathrm{KD}$ & $\begin{array}{l}\text { buy everything you need } \\
/ / \text { food // car parts // a big } \\
\text { variety of products }\end{array}$ & 4 & $\begin{array}{l}\text { get hold of clothes // many } \\
\text { types of clothes // something } \\
\text { interesting and elegant or } \\
\text { simply comfortable }\end{array}$ & 3 \\
\hline NF & $\begin{array}{l}\text { sells every kind of product } \\
/ / \text { anything that is added by } \\
\text { people // from toys to cars } \\
\text { or pets }\end{array}$ & 3 & $\begin{array}{l}\text { selling brand clothes and } \\
\text { shoes }\end{array}$ & 1 \\
\hline $\mathrm{AD}$ & $\begin{array}{l}\text { serious issues such as death, } \\
\text { domestic abuse etc // more } \\
\text { entertaining like reviews } \\
\text { of tv series// articles about } \\
\text { make-up and politics }\end{array}$ & 3 & $\begin{array}{l}\text { post a review of the book } \\
\text { they have recently read }\end{array}$ & 1 \\
\hline MF & $\begin{array}{l}\text { a variety of interviews } \\
/ / \text { gallery of photos } \\
\text { and drawings //articles } \\
\text { concerning lifestyle and art }\end{array}$ & 3 & $\begin{array}{l}\text { lectures from TED } \\
\text { conferences// you can submit } \\
\text { your proposal }\end{array}$ & 2 \\
\hline MG & $\begin{array}{l}\text { sell of purchase anything // } \\
\text { range of products available is } \\
\text { almost infinite }\end{array}$ & 2 & $\begin{array}{l}\text { humour and entertainment // } \\
\text { all kinds of images // current } \\
\text { trends from the Internet // } \\
\text { jokes or funny photos }\end{array}$ & 4 \\
\hline PD & $\begin{array}{l}\text { art-related content // buyable } \\
\text { prints of: photos, posters, } \\
\text { comic book covers }\end{array}$ & 2 & works & 1 \\
\hline KS & $\begin{array}{l}\text { a free course of English } \\
\text { language // a tutor that you } \\
\text { can communicate with }\end{array}$ & 2 & $\begin{array}{l}\text { a wide range of activities // } \\
\text { games and features that can } \\
\text { help you to learn a language } \\
/ / \text { fourteen languages that the } \\
\text { website offers }\end{array}$ & 3 \\
\hline MS & $\begin{array}{l}\text { teaching English // news } \\
\text { from all over the world // } \\
\text { news // interesting events that } \\
\text { are happening in vast cities // } \\
\text { tips how to use it to improve } \\
\text { your English // daily word }\end{array}$ & 6 & $\begin{array}{l}\text { what's going on around the } \\
\text { world }\end{array}$ & 1 \\
\hline AT & $\begin{array}{l}\text { buying coffee and healthy } \\
\text { products // communicating } \\
\text { with people from all over } \\
\text { the world // sounds of a } \\
\text { restaurant, university or even } \\
\text { a park }\end{array}$ & 3 & $\begin{array}{l}\text { learning website // grammar } \\
\text { and vocabulary sections } \\
/ / \text { informations sections // } \\
\text { economy, politics or culture } \\
{[\ldots] \text { from English-language }} \\
\text { countries }\end{array}$ & 4 \\
\hline
\end{tabular}




\begin{tabular}{|l|l|c|l|c|}
\hline EB & $\begin{array}{l}\text { learn about every type of } \\
\text { music from classics through } \\
\text { jazz to hip-hop //unusual } \\
\text { instruments used in forgotten } \\
\text { parts of the world }\end{array}$ & 2 & $\begin{array}{l}\text { strange facts // gripping } \\
\text { adventures of crazy people // } \\
\text { certain phenomena of nature }\end{array}$ & 3 \\
\hline AB & $\begin{array}{l}\text { young girl who projects and } \\
\text { makes alternative clothes and } \\
\text { various pieces of jewellery }\end{array}$ & 1 & $\begin{array}{l}\text { inlimited range of } \\
\text { informations }\end{array}$ & 1 \\
\hline AA & $\begin{array}{l}\text { English literature // English } \\
\text { authors, poems, novels } \\
\text { and genres // materials for } \\
\text { students }\end{array}$ & 3 & $\begin{array}{l}\text { news// music //sport // films } \\
\text { //science }\end{array}$ & 5 \\
\hline RB & \begin{tabular}{l} 
online shopping centre \\
\hline
\end{tabular}
\end{tabular}

The data can be interpreted in terms of relevance. It can be assumed that the greater the number of tokens, the more relevant the content. The absence of collocation tokens means that the student has not answered part of the question. As Tables 4 and 5 show, all students but two have mentioned both features for both websites. However, many students operate on a high level of generality, using general qualitative adjectives such as "easy (to navigate)", "pleasant (to navigate)", or "hard (to navigate)", which are either simply a repetition of the key term provided in the exam question, or its close paraphrase or its negation (cf. students $\mathrm{AF}, \mathrm{KD}$, $\mathrm{NF}, \mathrm{AD}, \mathrm{MF}, \mathrm{MG}, \mathrm{PD}, \mathrm{MS}, \mathrm{AT}$ and RB). Three of those students, namely MG, $\mathrm{KS}$ and $\mathrm{PD}$ use the evaluative adjective but support it with no evidence and one student, NF, seems not to understand the meaning of the key phrase.

When it comes to the second feature, i.e. the range of information/products available, there is a greater disproportion visible. First of all, there seems to be a great disproportion in the number of collocating items among the students, with $\mathrm{BD}$, who has 6 collocating tokens for site 1 and 7 tokens for site 2 on the one end of the spectrum and $\mathrm{AB}$ and $\mathrm{RB}$ on the other, with just one mention for each. MS's essay shows lack of balance between the tokens for site 1 (six tokens) and those for site 2 (one token).

Another line of analysis is to examine the range of vocabulary used. By comparing the collocations for site 1 and 2 used by one student, it is possible to examine how each of the sites is presented, i.e. can the student introduce variety and paraphrase or do they simply repeat the same words or phrases. And so, for example BD repeats the same phrases: "simply-designed menu" for the ease of navigation, and "diversity of different levels" and "well-written exercises" for the range of information/products available.

To sum up, the collocation analysis revealed the following:

- the majority of the students addressed both parts of the task; 
— the majority of the students had problems with the first part of the task in that they could not go beyond the simple repetition of the phrase used in the exam question;

- a few students had problems with justifying their opinion concerning the first part of the task, which may suggest that they lack appropriate vocabulary (or practical knowledge);

- while writing about similar websites, some students tend to repeat the same phrases, which may indicate that they are poor at reformulating their thoughts;

- the content of the essays in which the collocation does not exceed one or two tokens shows various degrees of irrelevance.

It gives immediate insight into the text structure, paragraph organization, superstructure layout and the level of correspondence between the original task and the actual student's output.

\section{Conclusion}

The procedure described above is thought to supplement the standard writing marking strategies in those areas where the marking seems to be most subjective and impressionistic, i.e. coherence and cohesion, layout and relevance. By focusing on reference chains, it is possible to evaluate text organization, paragraphing, content relevance and to some extent the vocabulary range. The presentation of the data in the tables allows for a quick comparison of students' output, which helps the examiner avoid a frequently asked question: How did I grade the previous essays for X?" In other words, in addition to answering the simple question, how well-written the essay is, we may answer the question how well-written is the essay in comparison to the essays written by other students. In my sample, the latter question proved to be a crucial one. The analysis of collocation revealed that the students have problems with finding relevant vocabulary to deal with the exam task successfully. But since these problems concerned all students, the sad implication is that they may not be the only ones to blame.

\section{References}

Beaugrande, R. de. 1980. Text, Discourse, and Process: Toward a Multidisciplinary Science of Texts. London: Longman.

Brown, G. \& G. Yule. 1983. Discourse Analysis. Cambridge: Cambridge University Press.

Carrell, P.L. 1982. "Cohesion is Not Coherence.” Tesol Quarterly 16:4. 479-488.

Cotton, F. \& K. Wilson. 2008. "An Investigation of Examiner Rating of Coherence and Cohesion in the IELTS Academic Writing Task 2.” IELTS Research Reports 12. 55-134.

Enkvist, N.E. 1975. Tekstilingvistiikan peruskäsitteitä. Jyväskylä: Gaudeamus. 
—. 1978. "Coherence, Pseudo-coherence, and Non-coherence.” In: Östman, J.O. (ed.). Cohesion and Semantics. Åbo: Meddelanden från Stiftelsens för Åbo Akademi Forskningsinstitut. 109128.

—. 1990. "Seven Problems in the Study of Coherence and Interpretability." In: Connor, U. \& A.M. Johns (eds.). Coherence in Writing: Research and Pedagogical Perspectives. Alexandria: TESOL. 9-28.

Fulcher, G. 1989. "Cohesion and Coherence in Theory and Reading Research." Journal of Research in Reading 12:2. 146-163.

Halliday, M.A.K. \& R. Hasan. 1976. Cohesion in English. Harlow: Longman.

Hasan, R. 1984. "Coherence and Cohesive Harmony." In: Flood, J. (ed.). Understanding Reading Comprehension: Cognition, Language, and the Structure of Prose. Newark: International Reading Association. 181-219.

—. 1985. "The Texture of a Text." In: Halliday M.A.K. and R. Hasan (eds.). Language, Context and Text: Aspects of Language in a Social-semiotic Perspective. Geelong: Deakin University Press. 70-96.

Källgren, G. 1979. "Some Types of Textual Cohesion and Their Effects on Texts." In: Pettersson, T. (ed.). Papers from the Fifth Scandinavian Conference of Linguistics. Stockholm: Almqvist \&Wiksell. 133-145.

Morgan, J.L. \& M.B. Sellner. 1980. "Discourse and Linguistic Theory.” In: Spiro, R.J., B.C. Bruce, \& W.F. Brewer (eds.). Theoretical Issues in Reading Comprehension: Perspectives from Cognitive Psychology, Linguistics, Artificial Intelligence, and Education. Hillsdale: Erlbaum. 165-200.

Renkema, J. 2004. Introduction to Discourse Studies. Amsterdam-Philadelphia: John Benjamins.

Tanskanen, S. 2006. Collaborating Towards Coherence: Lexical Cohesion in English Discourse. Amsterdam: Benjamins.

Van Peer, W. 1989. "The Concept of Cohesion: Its Empirical Status in a Definition and Typology of Texts." In: Conte, M.E., J.S. Petöfi, \& E. Sözer (eds.). Text and Discourse Connectedness: Proceedings of the Conference on Connexity and Coherence, Urbino, July 16-21 1984. Amsterdam-Philadelphia: John Benjamins. 291-308.

Widdowson, H.G. 1978. Teaching Language as Communication. Oxford: Oxford University Press.

\section{Internet sources}

Cambridge English Advanced. Handbook for teachers for exams from 2015. www.examenglish.com/ CAE/cae_writing.html. 